\section{Similar Sealability Between Bioceramic Putty Ready-To-Use Repair Cement and White MTA}

Fernanda Leal', Gustavo De-Deus², Claudia Brandão ${ }^{1}$, Aderval Luna ${ }^{3}$, Erick

Souza $^{4}$, Sandra Fidel ${ }^{1}$

\author{
'Department of Endodontics, \\ UERJ - State University of Rio de \\ Janeiro, Rio de Janeiro, RJ, Brazil \\ ${ }^{2}$ Unigranrio University, Rio \\ de Janeiro, RJ, Brazil \\ ${ }^{3}$ Department of Analytical Chemistry, \\ UERJ - State University of Rio de \\ Janeiro, Rio de Janeiro, RJ, Brazil \\ ${ }^{4}$ School of Dentistry, Florence \\ Institute, São Luis, MA, Brazil
}

\begin{abstract}
Correspondence: Dra. Fernanda Leal Fonseca de Carvalho, Rua lvone Cavaleiro, 184/101, Jardim Oceânico, Barra da Tijuca, 22620-290 Rio de Janeiro, RJ, Brasil. Tel: +55-21-24393960/ +55-21-7234-5811. e-mail: fernandaleal.endo@gmail.com
\end{abstract}

Key Words: bioceramic cement, MTA, root-end filling.

\section{Introduction}

Mineral trioxide aggregate (MTA) can be considered the repair cement closest to the ideal that has been yet developed due to its intrinsic remarkable biological and physical properties $(1,2)$. Much evidence support MTA as the gold-standard material for a series of clinical procedures like root-end filling, pulp capping, pulpotomy, apexogenesis, apical barrier formation in teeth with open apexes, repair of root perforations, and root canal filling $(2,3)$. Nevertheless, a couple of drawbacks can still be regarded to MTA, especially those related to manipulation and handling properties $(4,5)$.

White ProRoot MTA (WMTA; Dentsply Tulsa Dental Specialties, Tulsa, OK, USA) was introduced in 2002 to improve MTA clinical handling properties (6) by changing particle size. White ProRoot MTA contains smaller particles with a narrower range of size distribution compared with grey MTA $(7,8)$. Moreover, WMTA was also aimed at overcoming the noticeable dentine and gingival pigmentation caused by grey MTA (2). However, WMTA are not free from handling and setting-time drawbacks.

A fully labor-synthesized water-based bioceramic cement has been recently developed (iRoot BP Plus, Innovative BioCeramix Inc. Vancouver, BC, Canada) claiming to present improved handling properties over the traditional MTA. iRoot BP Plus is a putty ready-to-use cement developed for permanent root canal repair and filling applications. Unlike MTA, iRoot BP Plus claims to be a convenient, user-friendly reparative material as it is available ready to be used. According to the manufacturer,
iRoot BP Plus does not shrink during setting and is an insoluble, radiopaque and aluminium-free material based on a calcium silicate composition, which requires the presence of moisture to set and harden (www.ibioceramix. com) (9).

To date, the sealability of iRoot BP Plus used as retrofilling material has not been assessed. The present study was designed to investigate the root-end sealing ability of iRoot BP Plus. WMTA was used as a reference material for comparison. The recently developed glucose leakage under high-pressure model (10) was used to test the null hypothesis that there is no significant difference on the root-end sealability between WMTA and iRoot BP Plus.

\section{Material and Methods}

\section{Specimen Selection and Preparation}

Forty human maxillary incisors were selected, autoclaved and kept in $0.2 \%$ sodium azide for 30 days. After preparation of access cavities and location of canal orifices, apical patency was confirmed with a K-file size 15 (Maillefer Instruments, Ballaigues, Switzerland). The working length was established at $1 \mathrm{~mm}$ from the apex.

Instrumentation of the cervical and middle thirds of the canal was carried out using a crown-down flaring technique with sizes 5 to 3 Gates Glidden drills (Maillefer Instruments). The apical third was instrumented using K-Flexofiles sizes $60,55,50,45$ and 40 (Maillefer Instruments). After each instrument, $1 \mathrm{~mL}$ of freshly prepared $5.25 \%$ sodium hypochlorite ( $\mathrm{pH} 10.8)$ was used at a flushing rate of 1 $\mathrm{mL} / 1 \mathrm{~min}$. A total amount of $8 \mathrm{~mL} / 8 \mathrm{~min}$ of $\mathrm{NaOCl}$ flushing 
was used during instrumentation. A $3 \mathrm{~mL}$ of distilled water was used. Smear layer was removed using 17\% EDTA for 3 $\mathrm{min}$, followed by a final flush with $3 \mathrm{~mL}$ of distilled water drying of the canals with paper points. Crowns were then removed to standardize roots length in $15 \mathrm{~mm}$.

\section{Apicoectomy}

The apical $3 \mathrm{~mm}$ was resected perpendicularly to the root long axis with a diamond disc (\#7020; KG Sorensen, São Paulo, SP, Brazil). A ML accessory gutta-percha cone was inserted into the canal space and through the apical opening until tug-back was achieved. The apically extruded gutta-percha was sectioned. The root-end cavities were prepared with an ultrasonic device (NSK - Nakanishi Inc., Tokyo, Japan) and a 3-mm-long retro tip E32D (NSK Nakanishi Inc.). This way, 3-mm-deep standardized cavities were prepared.

The roots were randomly distributed with the aid of a computer algorithm (http://www.random.org) into 2 experimental groups $(n=15), 2$ control groups $(n=2)$ and 3 pilot groups $(n=2)$.

\section{Root-end Filling Procedures}

The prefitted gutta-percha cone served as a barrier for the condensation of the root-end filling material. After cement setting, gutta-percha was removed from each root canal. WMTA was prepared according to the manufacturer's recommendations. Two experimental groups were formed, which received either iRoot BP Plus or WMTA.

Both materials were placed into root-end cavities using a \#5 spatula, inserted by means of the same ultrasonic tip used for preparations and further compacted with a specific plugger (Paiva compactor, Odous de Deus, MG, Brazil). After root-end filling, all samples were stored in 100\% humidity for $72 \mathrm{~h}$ to allow sealers to set. Apicoectomy, preparation of root-end cavities and retrograde fillings were made by a single operator.

\section{Pilot Tests Assessing Glucose Reactivity}

Bernabé et al. (15) used vacuum to solve this potential drawback and to facilitate the penetration of the marker in case of presence of a void in the mass of the obturation. Based on the previous report by Shemesh et al. (11), a glucose reactivity pilot test with the 2 cements tested (iRoot BP Plus and WMTA) was performed in the present work. It is well-known that after $24 \mathrm{~h}$ contact the tracer react chemically itself with MTA-based materials (11). The goal of this pilot was to verify whether shorter periods of contact would also be influencing glucose concentrations and this way, determine the most appropriate pressure application time for this study.

Four human maxillary incisors roots were retrofilled with the materials tested ( 2 per material). Two additional roots remained unfilled. The apical portion of each sample was immersed into small flacons containing $4 \mathrm{~mL}$ of 0.2 $\mathrm{mg} / \mathrm{mL}$ glucose solution, one flacon per root. Additional 2 flacons were used as controls containing only $4 \mathrm{~mL}$ of glucose standard $(0.2 \mathrm{mg} / \mathrm{mL})$ solution. All flacons were kept at $37^{\circ} \mathrm{C}$ and a sample of $0.1 \mathrm{~mL}$ was taken after $30 \mathrm{~min}, 60$ $\mathrm{min}$, and $120 \mathrm{~min}$ of contact from each flacon. Each sample collected was analyzed using a glucose kit (Megazyme, Wicklow, Ireland) in a spectrophotometer (Camspec M 330, Leeds, United Kingdom) at a wavelength of $340 \mathrm{~nm}$ and the optical density (OD) statistically compared with the aid of the SPSS 17.0 software. Univariate analysis of variance was used to verify the effect of time of contact and cement on the OD of the glucose solution. Tukey's post-hoc test was used to compare the time points and Dunnett post-hoc used to compare the OD's between cements and glucose standard.

The test demonstrated that neither time of contact nor cements had influenced the OD of glucose solution $(p>0.05)$. There was no difference in OD between time frames $(p>0.05)$ and no difference between cements and glucose standard $(p>0.05)$. Based on the results of the pilot study, even though the two hours contact had demonstrated no significant glucose reduction in both tested cements, an experimental time of $60 \mathrm{~min}$ was chosen, in order to make it sure that no glucose reaction would occur.

\section{Assembled Double-Chamber and Glucose Leakage Measuring}

Teeth were placed into a device designed to measure glucose leakage $(12,13)$ (Fig. 1). Teeth were individually

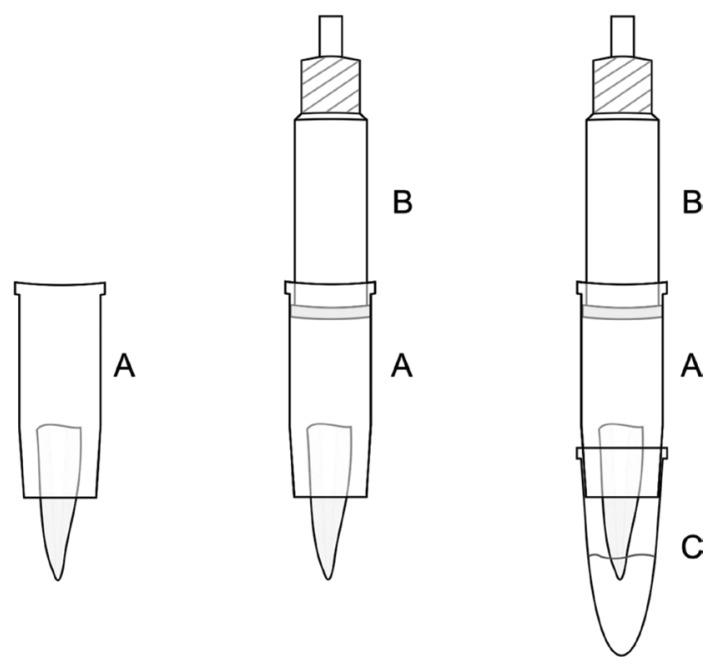

Figure 1. Sequence of assembled double-chamber dispositive. A: Maxillary chamber. B: Syringe connector. C: Lower chamber. 
inserted into an Eppendorf tube $(1.5 \mathrm{~mL})$ with apical 7 $\mathrm{mm}$ protruding through the end. The maxillary portion of the Eppendorf tube was connected to a plunger-less syringe containing $0.75 \mathrm{~mL}$ of $1 \mathrm{Mol} / \mathrm{L}$ glucose solution $(\mathrm{pH}=7.0 /$ density $=1.09 \times 103 \mathrm{~g} \bullet \mathrm{L}-1 /$ viscosity $=1.18 \times$ 10-3 Pa $\bullet$ s at $37^{\circ} \mathrm{C}$ ). The lower portion of the Eppendorf was inserted to another Eppendorf tube containing 0.75 $\mathrm{mL}$ of deionized water in such a way that $3 \mathrm{~mm}$ of the sample apex was immersed into the water. Low viscosity cyanoacrylate adhesive was used to seal all the interfaces and connections.

In the negative control group, a cover of two layers of nail polish was applied over the root surface of teeth with intact crowns. In the positive control group, root-end cavities were not filled nor covered. Before the beginning of the experiment, all samples were sterilized in ethylene oxide (BIOXXI Sterilization Services Ltd., Rio de Janeiro, RJ, Brazil).

The maxillary part of the syringe containing glucose solution was connected to a pressure source to create a headspace pressure of $103 \mathrm{kPa}$ per $60 \mathrm{~min}$. The present experimental set-up was constructed to run 30 experimental samples plus 2 controls simultaneously (Fig. 2). After that, a $10 \mu \mathrm{L}$ aliquot of solution was drawn from $\Xi$ the inferior Eppendorf using a micropipette and then analyzed using a glucose kit (Megazyme) in a UV-VIS s. spectrophotometer (Camspec) following a kinetic assay at $340 \mathrm{~nm}$ wavelengths to obtain the specific optical density (OD) value for each sample. OD values were converted into glucose concentrations $(\mathrm{g} / \mathrm{L})$. All readings were carried out in duplicate and the mean value was considered for statistical analysis.

\section{Statistical Analysis}

The preliminary analysis of the raw pooled data from the experimental groups did not show a normal distribution (D'Agostino and Person omnibus normality test), therefore statistical analysis was performed using non-parametric methods. The Mann-Whitney test was used to compare the two groups. The alpha-type error was set at 0.05 and Prisma 5.0 (GraphPad Software Inc., La Jolla, CA, USA) was used as the analytical tool.

\section{Results}

After $1 \mathrm{~h}$ of pressure application, no sign of glucose was detected in the inferior Eppendorfs in the negative control groups, whereas the samples in the positive control group displayed great volumes of glucose leakage after the same time period.

Mean and standard deviation, median and rank of glucose concentrations from the cements studied were respectively $0.8 \mathrm{~g} / \mathrm{L}( \pm 0.8), 1.4(0-3.6)$ for the iRoot BP Plus group and $1.2 \mathrm{~g} / \mathrm{L}( \pm 1.1), 1.3(0-2.5)$ for the ProRoot MTA group. There was no significant difference between glucose values observed in the iRoot BP Plus and white MTA ( $p>0.05$,

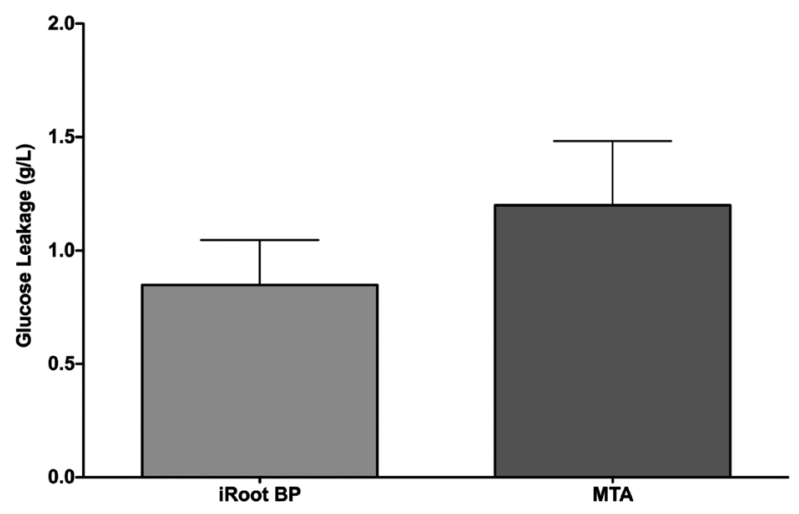

Figure 3. Column chart of the leakage results, illustrating the median and standard deviation in each experimental group.

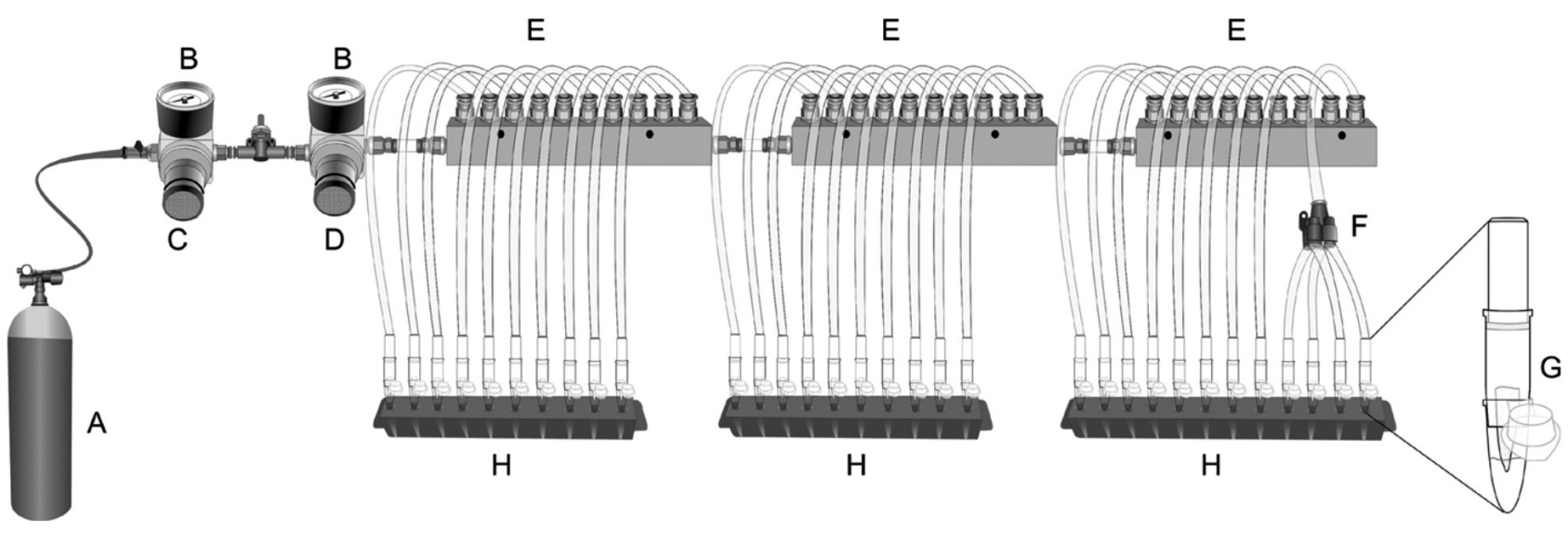

Figure 2. Experimental set-up for pressure distribution. A: Compressed air source. B: Manometer. C: Pressure controller of low sensitivity. D: pressure controller of high sensitivity. E: Distribution device with 10 exits. F: Connector with 4 exits. G: Double-chamber apparatus. H: Laboratorial support for Eppendorf tubes. 
Mann-Whitney). The median and standard deviations in each experimental group are illustrated in Figure 3.

\section{Discussion}

Glucose leakage model (GLM) is considered as a high-sensitive and clinical relevant sealability test (12) compared to other leakage models. However, the extended experimental period, the difficulty in keeping a bacteriafree system to avoid glucose consumption and the risk of water evaporation are still of concern while using GLM. Souza et al. (10) amplified pressure in the maxillary chamber of the GLM system to accelerate glucose leakage (from weeks to hours), reducing the risk of bacterial growth and long-term water evaporation with no reduction in the capability of detecting leaking samples.

In the current study, an appropriate pressure/time ratio enough to provide the passage of glucose by a throughand-through void (14) was adjusted performing a pilot test. Based on the pilot test results, it was decided to apply $103 \mathrm{Kpa}$ of pressure per $1 \mathrm{~h}$, as no reduction in glucose concentration was observed ( $p>0.05)$. Here, the root-end filled teeth were in contact with glucose solution instead of the large disc of the tested material used by Shemesh et al. (11). Thus, this considerably smaller quantity of material might explain the non-significant reduction even after the $2 \mathrm{~h}$ contact period.

The choose for a three times higher pressure than the pressure applied in the 24-h experiment originally performed by Souza et al. (10), can be explained by the reduced experimental time of $1 \mathrm{~h}$. Considering that a 120 $\mathrm{kPa}$ pressure application has been not shown to damage the integrity of the root filling (12), the $103 \mathrm{kPa}$ used in the present study was probably not detrimental to the integrity of root-end fillings.

MTA has presented along the years good sealability results in several studies $(3,16-20)$, so it is important that new endodontic materials display at least similar ability to prevent leakage as MTA.

Although little or inexistent literature could be retrieved regarding iRoot BP Plus cement, it displays the same composition as the iRoot SP root canal sealer with the difference that iRoot BP Plus presents a cement-like consistence. Some literature can be quoted for the iRoot SP sealer. It has been found to present similar sealing ability (9) and bonding adhesion to dentine (21) compared to AH Plus. It also displays low cytotoxicity (22) and biocompatibility (23).

Sarkar et al. (24) suggested that MTA initially produced a mechanical seal and further dissolved leading to the formation of hydroxyapatite crystals, which reacted with dentine to create a chemical adhesion. During setting reaction the calcium silicate present in the iRoot BP Plus produces calcium silicate hydrogel and calcium hydroxide. Calcium hydroxide partially reacts with the phosphate to form hydroxyapatite and water which may explain the comparable leakage results to WMTA observed in the present study ( $p>0.05)$. Additionally, the calcium silicate present in the cement is claimed to use moisture of the dentine resulting in a non-shrinking, bonding material (21). However, Kazem et al. (25) recently tested the sealing ability of a calcium-enriched mixture (CEM) cement as a root-end filling material and also concluded that CEM provides leakage results comparable to others commonly used root-end materials such as WMTA.

IRoot BP Plus is the first to represent a ready-to-use bioceramic cement class. Compared to the traditional MTA, this bioceramic cement represents a real evolution since it is able to overcome limitations on manipulation, handling and insertion (6).

Considering the present results, iRoot BP Plus can be expected as good repair cement material provided it is submitted to a complete scientific scrutiny. Some aspects as its biocompatibility, its osteogenic capacity and its long-term dimensional stability should be tested, as well as its setting reaction in clinical conditions. IRoot BP Plus represents a really innovative material due to its readyto-use presentation and the similar retrofilling sealing to WMTA, observed in this study.

On the basis of the present laboratory study, it was possible to observe that a ready-to-use bioceramic endodontic repair cement, iRoot BP Plus, had a similar ability to that of white ProRoot MTA in preventing glucose leakage as a root-end filling material.

\section{Resumo}

Este estudo foi desenhado para avaliar a capacidade de impedir a infiltração de glicose de um cimento reparador biocerâmico pronto para o uso, em comparação com o agregado trióxido mineral (MTA) branco. Após a instrumentação do canal radicular, os $3 \mathrm{~mm}$ apicais de incisivos superiores foram removidos, e retropreparos com $3 \mathrm{~mm}$ de profundidade foram realizados com ultra-som. As cavidades retrógradas foram preenchidas com os materiais testados ( 15 raizes por grupo). Todas as raizes foram montadas em um sistema de câmara dupla para avaliar a infiltração de glicose utilizando a aplicação de pressão de 15 psi. Depois de $1 \mathrm{~h}$, concentrações de glicose na câmara inferior foram medidas seguida de uma reação enzimática. Quatro raízes foram usadas como controle. 0 teste de Mann-Whitney verificou diferenças na infiltração de glicose entre os grupos e o teste de Tukey realizou comparações múltiplas. A significância foi estabelecida em $\alpha=5 \%$. Não houve diferença significante entre a média e a mediana comparando-se os grupos do iRoot BP Plus e o MTA branco. iRoot BP Plus teve uma capacidade semelhante ao do MTA branco na prevenção da infiltração de glicose como material retroobturador.

\section{References}

1. Torabinejad $M$, Chivian N. Clinical applications of mineral trioxide aggregate. J Endod 1999;25:197-205.

2. Parirokh M, Torabinejad M. Mineral Trioxide Aggregate: A comprehensive literature review - Part I: chemical, physical and antibacterial properties. J Endod 2010;36:16-27. 
3. Post LK, Lima FG, Xavier CB, Demarco FF, Gerhardt-Oliveira M. Sealing ability of MTA and amalgam in different root-end preparations and resection bevel angles: an in-vitro evaluation using marginal dye leakage. Braz Dent J 2010;21:416-419.

4. Asgary S, Parirokh M, Eghbal MJ, Brink F. Chemical differences between white and gray mineral trioxide aggregate. J Endod 2005;31:101-103.

5. Bortoluzzi EA, Broon NJ, Bramante CM, Felippe WT, Tanomaru Filho M, Esberard RM. The influence of calcium chloride on the setting time, solubility, disintegration, and $\mathrm{pH}$ of mineral trioxide aggregate and white Portland cement with a radiopacifier. J Endod 2009;35:550-554.

6. Chng HK, Islam I, Yap AUJ, Tong YW, Koh ET. Properties of a new rootend filling material. J Endod 2005;31:665-668.

7. Camilleri J, Montesin FE, Brady K, Sweeney R, Curtis RV, Pitt Ford TR. The constitution of mineral trioxide aggregate. Dent Mater 2005;21:297303.

8. Komabayashi T, Spangberg LSW. Comparative analysis of the particle size and shape of commercially available mineral trioxide aggregates and Portland cement: A study with a flow particle image analyzer. J Endod 2008;34:94-98.

9. Zhang W, Li Z, Peng B. Assessment of a new root canal sealer's apical sealing ability. Oral Surg Oral Med Oral Pathol Oral Radiol Endod 2009;107:79-82.

10. Souza EM, Wu M-K, Shemesh H, Bonetti-Filho I, Wesselink PR. Comparability of the results from two leakage models. Oral Surg Oral Med Oral Pathol Oral Radiol Endod 2008;106:309-313.

11. Shemesh $H$, Souza EM, Wu M-K, Wesselink PR. Glucose reactivity with filling materials as a limitation for using the glucose leakage model. Int Endod J 2008;41:862-872.

12. Xu Q, Fan M-W, Fan B, Cheung GSP, Hu H-L. A new quantitative method using glucose for analysis of endodontic leakage. Oral Surg Oral Med Oral Pathol Oral Radiol Endod 2005;99:107-711.

13. De-Deus G, Soares J, Leal F, Luna AS, Fidel S, Fidel RAS. Similar glucose pattern on smear-covered, EDTA-treated, and BioPure MTAD-treated dentin. J Endod 2008;34:459-462.

14. Pommel L, Camps J. Effects of pressure and measurement time on the fluid filtration method in endodontics. J Endod 2001;27:256-258.
15. Bernabé PFE, Gomes-Filho JE, Bernabé DG, Nery MJ, Otoboni-Filho JA, Dezan-Jr E, Cintra LTA. Sealing ability of MTA used as root end filling material: effect of the sonic and ultrasonic condensation. Braz Dent J 2013; 24:107-110.

16. Wu $\mathrm{M}-\mathrm{K}$, Kontakiotis $\mathrm{E}$, Wesselink $\mathrm{P}$. Long-term seal provided by some root-end filling materials. J Endod 1998; 24:557-60.

17. Yatsushiro J, Baumgartner JC, Tinkle J. Longitudinal study of the microleakage of two root-end filling materials using a fluid conductive system. J Endod 1998;24:716-719.

18. Lamb EL, Loushine RJ, Weller RN, Kimbrough WF, Pashley DH. Effect of root resection on the apical sealing ability of mineral trioxide aggregate. Oral Surg Oral Med Oral Pathol Oral Radiol Endod 2003;95:732-735.

19. Al-Hezaimi K, Naghshbandi J, Oglesby S, Simon JH, Rotstein I. Human saliva penetration of root canals obturated with two types of mineral trioxide aggregate cements. J Endod 2005;31:453-456.

20. De Bruyne MAA, De Bruyne RJE, De Moor RJG. Long-term assessment of the seal provided by root-end filling materials in large cavities through capillary flow porometry. Int Endod J 2006;39:493-501.

21. Ersahan S, Aydin C. Dislocation resistance of iRoot SP, a calcium silicate-based sealer, from radicular dentine. J Endod 2010;36:20002002.

22. Zhang W, Li Z, Peng B. Ex vivo cytotoxicity of a new calcium silicatebased canal filling material. Int Endod J 2010;43:769-774.

23. Zhang W, Li Z, Peng B. Effects of iRoot SP on mineralization-related genes expression in MG63 cells. J Endod 2010;36:1978-1982.

24. Sarkar NK, Caicedo R, Ritwik P, Moiseyeva R, Kawashima I. Physicochemical basis of the biological properties of mineral trioxide aggregate. J Endod 2005;31:97-100.

25. Kazem M, Mahjour F, Dianat O, Fallahi S, Jahankhah M. Root-end filling with cement-based materials: An in vitro analysis of bacterial and dye microleakage. Dent Res J 2013; 10:46-51.

Received October 27, 2012 Accepted July 25, 2013 